\title{
Sistema estomatognático e postura corporal na criança com alterações sensório-motoras***
}

\author{
Stomatognathic system and body posture in children with \\ sensoriomotor deficits
}

\author{
Daniela Cristina do Val* (fga.danieladoval@pop.com.br) \\ Suelly Cecília Olivan Limongi** \\ Fabíola Custódio Flabiano* \\ Ketley Cristine Linhares da Silva*
}

\begin{abstract}
*Fonoaudióloga. Especializada em Linguagem - Área: Síndromes e Alterações Sensório-Motoras pelo Curso de Especialização em

Fonoaudiologia da Faculdade de Medicina da Universidade de São Paulo. Colaboradora do Laboratório de Investigação Fonoaudiológica em Síndromes e Alterações Sensório Motoras da Faculdade de Medicina da Universidade de São Paulo.

**Fonoaudióloga. Professora Associada do Curso de Fonoaudiologia do Departamento de Fisioterapia, Fonoaudiologia e Terapia Ocupacional da Faculdade de Medicina da Universidade de São Paulo.

***Trabalho Realizado no Laboratório de Investigação Fonoaudiológica em Síndromes e Alterações SensórioMotoras da Faculdade de Medicina da Universidade de São Paulo.
\end{abstract}

Artigo de Pesquisa

Artigo Submetido a Avaliação por Pares

Conflito de Interesse: não

Recebido em 19.08.2004. Revisado em 12.07.2005; 26.08.2005; 28.09.2005.

Aceito para Publicação em 28.09.2005.

\begin{abstract}
Background: literature points that body posture is an important aspect in the treatment of children with sensorimotor deficits. Considering individuals with cerebral palsy, reflexes are often more intense than reactions of rectification and equilibrium, causing, therefore, a delay or obstacle in cervical, torso and hip control. This delay has as a consequence an impact on the Stomatognathic System. Aim: to verify the relation between body posture and the Stomatognathic System in this population, regarding posture and function, and its effectiveness in the process of speech-language intervention. Method: 17 children with sensorimotor deficits, aged between 1 and 6:3 years, were submitted to an initial assessment, followed by speech-language intervention and re-assessment. Speech-language intervention occurred for a period of 10 months, with weekly individual sessions, always in the presence of the caretaker. All sessions were transcribed in a specific protocol and the assessment and re-assessment sessions were videotaped. Results: a statistically significant improvement of stomatognathic system in $100 \%$ of the children was observed, not only of the isolated structures, but also of the whole system. The same was observed for the assessed functions. Conclusion: the improvement of body posture of the studied children favored significantly the development and improvement of the stomatognathic system regarding the aspects of posture and function.
\end{abstract}

Key Words: Stomatognathic System; Body Posture; Children; Sensorimotor Disorder.

\section{Resumo}

Tema: a literatura aponta a postura corporal como um aspecto importante no tratamento de crianças com alterações sensório-motoras. No caso do paralítico cerebral, os reflexos apresentam-se mais intensos do que as reações de retificação e de equilíbrio, inibindo-as, provocando assim um atraso ou impedimento do controle cervical, de tronco e de quadril, que se reflete no Sistema Estomatognático; Objetivo: verificar a relação entre a postura corporal e a adequação do Sistema Estomatognático nessa população, quanto à postura e funcionalidade e sua efetividade no processo terapêutico fonoaudiológico; Método: foram realizadas avaliação inicial, intervenção fonoaudiológica e reavaliação em dezessete crianças com alterações sensório-motoras, com idades entre um ano e seis anos e três meses. A intervenção terapêutica foi realizada durante dez meses, com sessões semanais individuais, sempre com a presença do cuidador. Todas as sessões foram transcritas em protocolo específico e a avaliação e a reavaliação foram gravadas em videoteipe; Resultados: observamos melhora estatisticamente significante dos aspectos do sistema estomatognático em $100 \%$ das crianças, tanto nas estruturas isoladamente, quanto em conjunto. $\mathrm{O}$ mesmo foi observado com relação às funções; Conclusão: a adequação da postura corporal das crianças estudadas favoreceu de forma significativa o desenvolvimento e adequação do sistema estomatognático quanto à postura e a funcionalidade.

Palavras-Chave: Sistema Estomatognático; Postura Corporal; Alterações Sensório-Motoras.

VAL, D. C. do.; LIMONGI, S. C. O.; FLABIANO, F. C. SILVA, K. C. L. da. Stomatognathic system and body posture in children with sensoriomotor deficits (original A title: Sistema estomatognático e postura corporal na criança com alterações sensório-motoras).Pró-Fono Revista de Atualização Científica, Barueri (SP), v. 17, n. 3 , E -3 p. 345-354, set.-dez. 2005. 


\section{Introduction}

The normal neuropsychomotor development is characterized by the gradual acquisition of postural control with the emergence of righting and balance reactions. This process depends on the integrity of the Central Nervous System (CNS) and evolves in such an orderly way that each stage is a consequence of the previous and necessary to the next one.

The righting and balance reactions development allows the individual to keep his posture and balance of the head, trunk, inferior extremities under all normal circumstances, against the gravitational action, while the arms and hands remain free to explore the environment.

In children with sensorimotor disorders due to brain lesion, this development is slow and disorganized, many times the primary motor behavior persists and abnormal motor patterns emerge. Therefore, as in the normal motor development, the development of the pathological signs also follows a cefalo-caudal direction (Bobath, 1984).

In the case of a brain damaged, the pathological reflexes are more intense than the righting and balance reactions, inhibiting them and provoking therefore, a delay or impairment of the cervical control of the trunk and hips. As a consequence, some stomatognathic system disorders are observed (Larnert \& Ekberg, 1995; Aurélio et al., 2002; Fung et al., 2002; West \& Redstone, 2004; Redstone \& West, 2004).

The tonus, the posture and movements of the phonoarticulatory organs may be altered in the child with Cerebral Palsy, causing a deficit in the performance of sucking, swallowing, chewing, breathing and in the coordination between these functions, as well as in the oral motor skills necessary for the speech articulation (Seacero, 1999; Limongi, 2003).

The body posture is being reported in the literature as an important aspect that should be taken into account, specially in the treatment of children with sensorimotor disorders who present reduced postural control and feeding problems of moderate and severe degree (Verzoni \& Limongi, 1998; Seacero, 1999; Gisel et al., 2000; Finnie, 2000; Furkim et al., 2003; Limongi, 2003; Fung et al., 2004; West \& Redstone, 2004; Redstone \& West, 2004), which many times are addressed as child dysphagy, leading to important respiratory tract infections, such as pneumonia, usually recurrent, and that clinically end up bringing even more damages to these children's development ( Sullivan et al., 2000; Motion et al., 2002; Gisel et al., 2003; Levy \& Rainho, 2003; Sleigh et al., 2004).

The inadequate positioning of the child during feeding may be the factor of greatest contribution to feeding disorders, once if the head is not aligned with the neck and trunk, the child may present excessive extension or flexion of head and neck, which is an extremely damaging posture for an effective feeding (Wolf and Glass, 1992); Schwartzman, 2000).

Therefore, the postures used during the feeding of children with Cerebral Palsy must aim at an interruption of the pathological reflex patterns in order to enable the isolated movements of arms, head, jaw, tongue and lips (Limongi, 1981).

Despite the body posture be described in several studies as an associated factor to feeding problems of children with sensorimotor disorders, its relationship with the stomatognathic system has not yet been precisely investigated. Therefore, the purpose of this study was to verify the relation between the body posture and the adequacy of the Stomatognathic System as regards to posture and functionality in children with sensorimotor disorders, and its efficacy in the speech-language therapy.

\section{Method}

This research was approved by the Ethics Committee for Research Projects Analysis (CAPPesq) of the Clinical Board of Hospital das Clínicas of the Univerity of São Paulo Medicine School (FMUSP), under protocol no. 078/03.

Seventeen children with syndromic and nonsyndromic sensorimotor disorders took part in this research, ranging in age from 1 year and 6 years and 3 month. Children attended the Laboratory of Speech-language Investigation in Syndromes and Sensorimotor Disorders (LIF-SASM) of FMUSP and had neurological and/or genetical assistance. The variable gender was not considered as an excluding factor, once it doesn't interfere with the data collecting and treatment. Parent or legal guardians signed and agreed with the Informed Consent Term.

In the first phase of the study, an initial evaluation was performed in order to gather information about the feeding process aspects, the child's body posture and the anatomo-functional conditions of the Stomatognathic System that are 
part of the Stomatognathic System Evaluation Protocol used in the LIF-SASM.

In the second phase of the study, a speechlanguage intervention was carried out during approximately 10 months. It was composed by weekly therapies with individual sessions of 45 minutes in the presence of the carer to whom were given orientations regarding the postural adequacy, specially during feeding, appropriate utensils, such as spoon, glass, bottle beak, etc and exercises to be preformed at home during the week.

All sessions were registered on a specific protocol of our service (Limongi et al., 2000), including the description of the situations, and the first (initial evaluation) and the last (re-evaluation) sessions were videotaped. During the therapy sessions, the following issues were approached: the adequacy of body posture, as well as the adequacy of orofacial structures regarding tonus, mobility, posture, responsivity to stimuli, and adequacy of the stomatognathic function including orientations about the type of food, the presentation rhythm and the instrument used.

In the third phase, the re-evaluation was performed.

For data analysis, the two videotape recordings and the descriptive protocols of the sessions were used, in a way that the data were qualitative and quantitative analyzed.

The statistical analysis involved two tests: the Chi-Square for Independency aiming at a qualitative association of the child's body posture with all variables referring to the stomatognathic system; and the Two Proportion Equality test for the comparison between data obtained in the initial evaluation with those obtained in the re-evaluation.

For each result a p-value was determined. Following the statitician's orientation, the significance level was 0,15 , once the $n$ of the sample, although significant, was small $(n=17)$. Furthermore, several studies point out that in this population even a small improvement is very significant. And, exactly because of the importance of all positive answers in this population, we considered the values between $15,1 \%$ and $29,9 \%$ as tendencious data.

The basic theory foundamentation followed in this research was provided by the Neuroevolutive approach - Bobath Method.

\section{Results}

Fisrtly, the relationship between the child's Body Posture (in the initial evaluation and in the re-evaluation) and the following items and respective sub-items were analyzed: Stomatognathic Structures: Lips (Posture, Tonus and Mobility), Tongue (Posture, Tonus and Mobility), Cheeks (Tonus and Mobility); Stomatognathic Functions: Sucking (Labial Sealing, Efficiency/Strenth, Power, Beak/ Straw Prension, and Coordination with breathing and swallowing), Chewing (Jaw movements, Tongue movements, Efficency, Lips posture, and Coordination with breating and swallowing), Swallowing (Liquid, Semi-solid and Solid food, and Coordination with breathing). Each item was classified as "adequate" (when most of the subitems were adequate), "developing" (when half of the sub-items were adequate) and "inadequate" (when most of the sub-items were inadequate).

Comparing the data obtained during the initial evaluation to those obtained with the re-evaluation regarding the child's Body Posture, we observed a statistically significant improvement ( $\mathrm{p}$ value $=0,001$ ) since the percentage of children who presented adequate body posture raised from $35,3 \%$ in the initial evaluation to $94,1 \%$ in the reevaluation, as shows Graph 1.

Analyzing the Stomatognathic Structures as a whole, we observed a statistically significant relation ( $\mathrm{p}$-value $=0,004$ ) when comparing the data obtained in the initial evaluation with those obtained in the re-evaluation. The percentage of children who presented adequate Stomatognathic Structures raised from $11,8 \%$, in the initial evaluation, to $58,9 \%$, in the re-evaluation.

Analyzing the Stomatognathic Structures individually (lips, tongue and cheeks), we observed significant improvements concerning the Lips and Tongue when comparing the data obtained in the initial evaluation to those obtained in the reevaluation. The percentage of children who presented adequate Lips raised form $11,8 \%$ in the initial evaluation to $58,9 \%$ in the re-evaluation and the percentage of children who presented adequate Tongue raised from $0 \%$ in the initial evaluation to $29,4 \%$ in the re-evaluation. Concerning the item Cheeks, 5,9\% of the children presented adequacy of this item in the initial evaluation and this percentage remained the same in the re-evaluation. However, the percentage of children who presented developing Cheeks raised from 23,5\% in the initial evaluation to $52,9 \%$ in the reevaluation. Such improvement was statistically significant for all items (Lips, Tongue and Cheeks), as shown in Table 1. 
According to Table 2, concerning the relationship between the child's Body Posture and the item Lips, it's possible to see that in the initial evaluation only one child $(5,9 \%)$ presented adequate Lips associated with adequate Body Posture and 10 children $(58,9 \%)$ presented inadequate Lips associated with inadequate Body posture. In the re-evaluation, these numbers became 9 children $(52,9 \%)$ and no children $(0 \%)$ respectively. However, the association between the item Lips and the child's Body Posture was not statistically significant, either in the initial evaluation ( $p$-value $=0,643)$ or in the re-evaluation ( $p$-value $=$ $0,388)$.

Table 3, concerning the relationship between the child's Body posture and the item Tongue, shows that none of the children $(0 \%)$ presented adequate Tongue associated with adequate Body Posture and $11(64,8 \%)$ children presented inadequate Tongue associated with inadequate Body Posture in the initial evaluation. In the reevaluation, these numbers became 5 children $(29,4 \%)$ and 1 child $(5,9 \%)$ respectively. Nevertheless, the association between the item Tongue and the child's Body Posture was not statistically significant, either in the initial evaluation $(p$-value $=1)$ or in the re-evaluation ( $p$ value $=0,506$ ).

As regards to the child's Body Posture and the item Cheeks, we observed that none of the children $(0 \%)$ presented adequate Cheeks associated with adequate Body Posture and 9 children $(52,9 \%)$ presented inadequate Cheeks associated with inadequate Body Posture in the initial evaluation. In the re-evaluation, these numbers became 1 child $(5,9 \%)$ and 1 child $(5,9 \%)$ respectively. Furthermore, it's possible to observe that 3 children $(17,6 \%)$ and 9 children $(52,9 \%)$ presented dveloping Cheeks associated with adequate Body posture in the initial evaluation and in the re-evaluation respectively. The data described above reveal the existence of a statistically significant association between the items Body Posture and Cheeks only in the initial evaluation, as shows Table 4.

Analyzing the Stomatognathic Functions as a whole, we observe that $47,1 \%$ of the children presented adequacy of this item in the initial evaluation and this percentage raised to $52,9 \%$ in the re-evaluation. However, this improvement was not statistically significant ( $\mathrm{p}$-value $=0,492$ ).

Analyzing the Stomatognathic Functions individually, we observed an expressive qualitative improvement of Sucking, Chewing and Swallowing when comparing the data obtained in the initial evaluation to those obtained in the re-evaluation. Concerning the function of Sucking, the percentage of adequacy raised from $52,9 \%$ in the initial evaluation to $76,5 \%$ in the re-evaluation. Concerning the function of Chewing, the percentage of adequacy raised from $23,5 \%$ in the initial evaluation to $52,9 \%$ in the re-evaluation. As regards to the function of Swallowing, the percentage of adequacy raised from $23,5 \%$ in the initial evaluation to $41,1 \%$ in the re-evaluation. Nevertheless, such improvement was statistically significant only for the item Chewing, as it can be seen in Table 5 .

GRAPH 1. Data comparison regarding the child's Body Posture in the evaluation and in the re-evaluation:

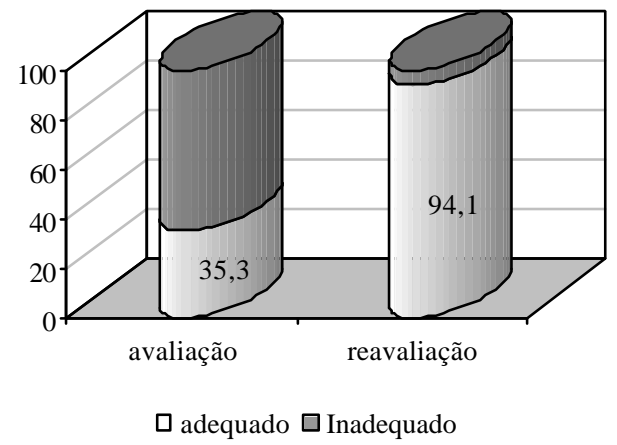

TABELA 1. Data comparison regarding the Stomatognathic System's Structures (Lips, Tongue and Cheeks) in the initial evaluation and in the re-evaluation.

\begin{tabular}{ccc|ccc} 
& & Adequado & Evolução & Inadequado & p-valor \\
\hline \multirow{2}{*}{ estruturas } & avaliação & $11,8 \%$ & $0 \%$ & $88,2 \%$ & \\
& reavaliação & $58,9 \%$ & $0 \%$ & $41,1 \%$ & 0,004 \\
\multirow{2}{*}{ lábios } & avaliação & $11,8 \%$ & $0 \%$ & $88,2 \%$ & \\
& reavaliação & $58,9 \%$ & $0 \%$ & $41,1 \%$ & 0,004 \\
& & & & & \\
língua & avaliação & $0 \%$ & $0 \%$ & $100 \%$ & \\
& reavaliação & $29,4 \%$ & $0 \%$ & $70,6 \%$ & 0,015 \\
& avaliação & $5,9 \%$ & $23,5 \%$ & $70,6 \%$ & \\
bochechas & reavaliação & $5,9 \%$ & $52,95 \%$ & $41,15 \%$ & 0,084 \\
\hline
\end{tabular}


TABLE 2. Association between the child's Body Posture and the item Lips in the initial evaluation and in the re-evaluation.

\begin{tabular}{|c|c|c|c|c|c|}
\hline \multirow{2}{*}{\multicolumn{2}{|c|}{ Lábios }} & \multicolumn{2}{|c|}{ Avaliação } & \multicolumn{2}{|c|}{ Reavaliação } \\
\hline & & Adequado & Inadequado & Adequado & Inadequado \\
\hline \multirow{4}{*}{$\begin{array}{l}\text { postura da } \\
\text { criança }\end{array}$} & adequado & 1 & 5 & 9 & 7 \\
\hline & inadequado & 1 & 10 & 1 & 0 \\
\hline & TOTAL & 2 & 15 & 10 & 7 \\
\hline & $\mathrm{p}$-valor & \multicolumn{2}{|c|}{0,643} & \multicolumn{2}{|c|}{0,388} \\
\hline
\end{tabular}

TABLE 3. Relação entre a postura corporal da criança e o item língua, na avaliação e reavaliação.

\begin{tabular}{cccccc}
\multirow{2}{*}{ Língua } & \multicolumn{2}{c}{ Avaliação } & \multicolumn{2}{c}{ Reavaliação } \\
\cline { 3 - 6 } & & Adequado & Inadequado & Adequado & Inadequado \\
postura da & adequado & 0 & 6 & 5 & 11 \\
criança & inadequado & 0 & 11 & 0 & 1 \\
& TOTAL & 0 & 17 & 5 & 12 \\
& & & 1,0 & & \multicolumn{2}{c}{0,506} \\
\hline
\end{tabular}

TABLE 4. Association between the child's Body Posture and the item Tongue in the initial evaluation and in the re-evaluation.

\begin{tabular}{|c|c|c|c|c|c|c|c|}
\hline \multirow{2}{*}{\multicolumn{2}{|c|}{ Bochechas }} & \multicolumn{3}{|c|}{ Avaliação } & \multicolumn{3}{|c|}{ Reavaliação } \\
\hline & & A & Evolução & I & A & Evolução & I \\
\hline \multirow{4}{*}{$\begin{array}{c}\text { postura } \\
\text { da criança }\end{array}$} & A & 0 & 3 & 3 & 1 & 9 & 6 \\
\hline & I & 1 & 1 & 9 & 0 & 0 & 1 \\
\hline & TOTAL & 1 & 4 & 12 & 1 & 9 & 7 \\
\hline & $\mathrm{p}$-valor & & 0,145 & & & 0,468 & \\
\hline
\end{tabular}

Legenda: A = Adequado; I = Inadequado.

TABLE 5. Data comparison regarding the Stomatognathic Functions (Sucking, Chewing and Swallowing) in the initial evaluation and in the re-evaluation.

\begin{tabular}{|c|c|c|c|c|c|}
\hline & & Adequado & Evolução & Inadequado & p-valor \\
\hline \multirow{2}{*}{ funções } & avaliação & $47,1 \%$ & $0 \%$ & $52,9 \%$ & \multirow[b]{2}{*}{0,492} \\
\hline & reavaliação & $58,9 \%$ & $0 \%$ & $41,1 \%$ & \\
\hline \multirow{2}{*}{ sucção } & avaliação & $52,95 \%$ & $17,6 \%$ & $29,45 \%$ & \multirow[b]{2}{*}{0,419} \\
\hline & reavaliação & $76,5 \%$ & $5,9 \%$ & $17,6 \%$ & \\
\hline \multirow{2}{*}{ mastigação } & avaliação & $23,5 \%$ & $0 \%$ & $76,5 \%$ & \multirow[b]{2}{*}{0,078} \\
\hline & reavaliação & $52,9 \%$ & $0 \%$ & $47,1 \%$ & \\
\hline \multirow{2}{*}{ deglutição } & avaliação & $23,5 \%$ & $5,9 \%$ & $76,5 \%$ & \multirow[b]{2}{*}{0,290} \\
\hline & reavaliação & $41,2 \%$ & $5,9 \%$ & $52,9 \%$ & \\
\hline
\end{tabular}

Concerning the relationship between the item Sucking and the child's Body Posture, we can observe that in the evaluation 5 children $(29,4 \%)$ presented adequate Body Posture associated with adequate Sucking and other 5 children $(29,4 \%)$ presented inadequate Body Posture associated with inadequate Sucking. Furthermore, one child $(5,9 \%)$ presented a developing Sucking associated with adequate Body Posture. In the re-evaluation, these numbers became 13 children $(76,5 \%)$, zero children $(0 \%)$ and zero children $(0 \%)$ respectively. The quantitative data analysis revealed the existence of a statistically significant association between the child's Body posture and the item Sucking, either in the initial evaluation ( $\mathrm{p}$ value $=0,114$ ) and in the re-evaluation ( $p$ value $=0,001$ ), as shows Table 6 .

Concerning the relationship between the child's Body Posture and the item Chewing, we observed that in the initial evaluation only one child $(5,9 \%)$ presented adequate Chewing associated with adequate Body Posture and 8 children $(47,1 \%)$ presented inadequate Chewing associated with inadequate Body Posture. In the re-evaluation, the numbers were 9 children $(52,9 \%)$ and one child $(5,9 \%)$ respectively. The quantitative data analysis did not reveal a statistically significant association between the child's Body Posture and Chewing in the initial evaluation ( $\mathrm{p}$-value $=0,622$ ). However, in the re-evaluation, it was observed an association tendency between these two items ( $p$-value=0,274), as shows Table 7.

Concerning the association between the child's Body Posture and the item Swallowing, we observed that in the initial evaluation 2 children $(11,8 \%)$ presented adequate Swallowing associated with adequate Body Posture and 8 children $(47,1 \%)$ presented inadequate Swallowing associated with inadequate Body Posture. In the re-evaluation, these numbers were 7 children $(47,1 \%)$ and 1 child $(5,9 \%)$, respectively. Additionally, in the evaluation we observed that no children presented a developing Swallowing associated with adequate Body Posture. In the re-evaluation this number became 1 child $(5,9 \%)$. The quantitative data analysis did not reveal a statistically significant association between the child's Body Posture and the item Swallowing, either in the initial evaluation ( $p$-value $=0,624)$ or in the re-evaluation ( $p$ value $=0,624)$. Such results may be better seen in Table 8 . 
TABLE 6. Association between the child's Body Posture and the item Sucking in the initial evaluation and in the re-evaluation.

\begin{tabular}{ccccccccc}
\multicolumn{2}{c}{} & \multicolumn{2}{c}{ Sucção } & Avaliação & & \multicolumn{2}{c}{ Reavaliação } \\
& & Adequado & Evolução & Inadequado & Adequado & Evolução & Inadequado \\
\hline \multirow{2}{*}{$\begin{array}{c}\text { postura } \\
\text { criança }\end{array}$} & adequado & 5 & 1 & 0 & 13 & 0 & 3 \\
\hline & inadequado & 4 & 2 & 5 & 0 & 1 & 0 \\
\hline & TOTAL & 9 & 3 & 5 & 13 & 1 & 3 \\
\hline
\end{tabular}

TABLE 7. Association between the child's Body Posture and the item Chewing in the initial evaluation and in the re-evaluation.

\begin{tabular}{|c|c|c|c|c|c|}
\hline \multirow{2}{*}{\multicolumn{2}{|c|}{ Mastigação }} & \multicolumn{2}{|c|}{ Avaliação } & \multicolumn{2}{|c|}{ Reavaliação } \\
\hline & & Adequado & Inadequado & Adequado & Inadequado \\
\hline \multirow{4}{*}{ postura da criança } & adequado & 1 & 5 & 9 & 7 \\
\hline & inadequado & 3 & 8 & 0 & 1 \\
\hline & TOTAL & 4 & 13 & 9 & 8 \\
\hline & p-valor & \multicolumn{2}{|c|}{0,622} & \multicolumn{2}{|c|}{0,274} \\
\hline
\end{tabular}

TABLE 8. Association between the child's Body Posture and the item Swallowing in the initial evaluation and in the re-evaluation.

\begin{tabular}{cccccccc}
\multicolumn{2}{c}{} & \multicolumn{2}{c}{ Deglutição } & Avaliação & & \multicolumn{2}{c}{ Reavaliação } \\
& & Adequado & Evolução & Inadequado & Adequado & Evolução & Inadequado \\
\hline \multirow{2}{*}{$\begin{array}{c}\text { postura } \\
\text { criança }\end{array}$} & adequado & 2 & 0 & 4 & 7 & 1 & 8 \\
\hline & inadequado & 2 & 1 & 8 & 0 & 0 & 1 \\
\hline & TOTAL & 4 & 1 & 12 & 7 & 1 & 9,624 \\
\hline
\end{tabular}

\section{Discussion}

Comparing the data obtained during the initial evaluation to those obtained during the reevaluation, we can observe a statistically significant improvement concerning the adequacy of the Body Posture as well as the anatomofunctional aspects of the Stomatognathic System. Therefore, the adequacy of the child's Body Posture led to an anatomo-functional improvement of the Stomatognathic System in $100 \%$ of the children, although in different degrees, according to the severity of each case.

Silva et al. (2004) pointed out that the adequacy of the Body Posture also interferes with breathing as regards to the mode and rhythm, favouring its coordination with the other Stomatognathic System's functions (sucking, chewing and swallowing). As a result, we observed that the feeding process became more effective and safe, avoiding the progression of malnutrition (Troughton \& Hill, 2001; Fung et al., 2002) and of important infections of the respiratory tract, such as pneumonia caused by broncoaspirations (Newman, 2000; Aurélio et al., 2002; Gisel et al., 2003; Fung et al., 2004; Sleigh et al., 2004; West \& Redstone, 2004).

Such results corroborate the literature which points out that the Body Posture is an important aspect that should be taken into account in the treatment of children with sensorimotor disorders who present reduced postural control and feeding problems of moderate to severe degrees (Verzoni \& Limongi, 1998; Seacero, 1999; Finnie, 2000; Gisel et al., 2000; Dusick, 2003; Limongi, 2003; West \& Redstone, 2004).

Furthermore, these results support the hypothesis of the association between the global 
posture control and the oral structures, existing therefore, a reciproc influence of the Body Posture in the oral structures and vice-versa (Gisel et al., 2000; Pinnington \& Hegarty, 2000; Levi \& Rainho, 2003; West \& Redstone, 2004; Redstone \& West, 2004).

During the initial evaluation we observed a very high percentage of children with disorders in the Stomatognathic Structures $(88,2 \%)$. The Tongue was the most affected structure (by $100 \%$ of the children), followed by the Lips $(88,2 \%)$ and the Cheeks $(70,6 \%)$. In the re-evaluation, with the adequacy of the child's Body Posture, these numbers were reduced to the half, becoming $41,1 \%$, $41,1 \%, 70,6 \%$ and $41,1 \%$, respectively.

Our study pointed out that $53,1 \%$ of the children presented problems regarding the Stomatognathic Functions of Sucking, Chewing and Swallowing in the initial evaluation, as did Reilly and Skuse (1992). However, with the adequacy of the Body Posture, this percentage was reduced to $41,1 \%$. In the initial evaluation, the function of Chewing presented higher percentage of alteration among the studied children $(76,5 \%)$, followed by Swallowing (70,6\%) and Sucking $(29,4 \%)$. In the re-evaluation these numbers were reduced to $47,1 \%, 52,9 \%$ and $17,6 \%$ respectively.

According to Wolf and Glass (1992), the quality of the body muscle tonus and the child's posture are inter-related with the physiological control and the oral-motor control during feeding. Besides, the child's muscle tonus may also influence on feeding position, for which the head, neck and trunk alignment is crucial. For the authors, the alignment of the head and neck with the trunk is a key component for obtaining the ideal feeding position and, therefore, they stress that the inadequate body positioning may be the factor of greatest contribution for feeding disfunctions.

Thus, the excessive head and neck extension is usually harmfull for the efficient feeding, once when the head is in a hyper-extensive position, the larynx elevation skill for protection of the airway is damaged, resulting in a laringeal aspiration of the food. The same way, the neck extension may lead to a tongue protrusion or to retraction patterns, as well as to exagerated jaw movements, resulting in an inifficient sucking (Wolf \& Glass, 1992; Larnert \& Ekberg, 1995; Pinnington \& Hegarty, 2000; Redstone \& West, 2004)

Our study agrees with the above authors, once the inhibiting of the Pathological Reflexes, either Oral and Postural, and the muscle tonus control allowed the maintainance of a more appropriate posture of the child (head and neck alignment with the trunk) during feeding, permitting a safer and more efficient feeding.

We can also verify, from the therapeutic practice point of view, that the intervention period was effective, evidencing the importance of the work done directly with the child and indirectly through orientations given to the carer.

This relationship can also be seen in the study of Haberfellner et al. (2001), that points out a significant improvement regarding the feeding skills (including significant weigh gain) after one year of intra-oral therapy in 20 children with Cerebral Palsy who presented dysphagy.

During the clinical practice, we observed the inadequate positioning of the children by the carers, many times due to difficulties in manipulating children with altered body patterns. They leaned the children, almost lying them down, with the intention of facilitating their feeding (Seacero, 1999). This incorrect positioning leads to a maintainance of pathological postural patterns interfereing with the oral-motor functions, besides facilitating the occurence of laringeal penetrations and aspirations (larnert \& Ekberg, 1995).

Lang (2002) reported the importance of parents participation in their children's treatment. In our study, the active participation of parents/carers in the therapies, transporting to the family activity the experience of correct positioning the child during feeding, in a ludic moment or even in the locomotion was of fundamental importance. This participation provided a better global development of the children, concerning the feeding and a more effective manipulation and exoploration of their environment.

\section{Conclusion}

From these results we can conclude that the adequacy of the body posture of children with sensorimotor disorders favoured, in a significant way, the development and adequacy of the Stomatognathic System regarding the posture and the functionality. In this process, the speechlanguage therapy was an effective and fundamental resource for the optimization of such aspects in these children. 


\section{Referências Bibliográficas}

AURÉLIO, S. R.; GENARO, K. F.; FILHO, E. D. M. Análise comparativa dos padrões de deglutição de crianças com paralisia cerebral e crianças normais. Revista Brasileira de Otorrinolaringologia, São Paulo, v. 8, n. 2, p. 167-173, mar.-abr. 2002.

BOBATH, K. Uma base neurofisiológica para o tratamento da paralisia cerebral. São Paulo: Manole, 1984.

DUSICK, A. Investigation and management of dysphagia. Semin. Pediatr. Neurol., v. 10, n. 4, p. 255-264, dec. 2003. FINNIE, N. R. O manuseio em casa da criança com paralisia cerebral. São Paulo: Manole, 2000.

FUNG, E. B.; SAMSON-FANG, L.; SALLINGS, V. A.; CONAWAY, M.; LIPTAK, G.; HENDERSON, R. C.; WORLEY, G.; O'DONNELL, M.; CALVERT, R.; ROSENBAUM, P.; CHUMLEA, W.; STEVENSON, R. D. Feeding dysfunction is associated with poor growth and health status in children with cerebral palsy. Am. Diet. Assoc., v. 102, n. 3, p. 361-73, mar. 2002.

FUNG, C. W.; KHONG, P. L.; GOH, W.; WONG, V. Videofluoroscopic study of swallowing in children with neurodevelopmental disorders. Pediatri. Int., v. 46, n. 1, p. 26-30, feb. 2004.

FURKIM, A. M.; BEHLAU, M. S.; WECKX, L. L. M. Avaliação clínica e videolfuoroscópica da deglutição em crianças com paralisia cerebral tetraparética espástica.Arq. Neuro-Psiquiatr, São Paulo, v. 61, n. 3A, p. 611-616, set. 2003.

GISEL, E. G.; SCHUWARTZ, S.; PETRYK, A.; CLARKE, D.; HABERFELLNER, H. Whole body mobility after one year of intraoral appliance therapy in children with cerebral palsy and moderate eating impairment. Dysphagia, v. 15, n. 4, p. 226-235, 2000.

GISEL, E. G.; TESSIER, M. J.; LAPIERRE, G.; SEIDMAN, E.; DROVIN, E.; FILION, G. Feeding management of children with severe cerebral palsy and eating impairment: an exploratory study. Phys. Occup. Ther. Pediatr., v. 23, n. 2, p. 19-44, 2003.

HABERFELLNER, H.; SCHWARTZ, S.; GISEL, E. G. Feeding skills and growth after one year of intraoral appliance therapy in moderately dysphagic children with cerebral palsy. Dysphagia, v. 16, n. 2, p. 83-96, spring 2001.

LANG, F. J. Deglutition disorders in early childhood. Rev. Med. Suisse Romande, v. 122, n. 6, p. 283-287, jun. 2002.

LARNERT, G.; EKBERG, O. Positioning in proves the oral and pharyngeal swallowing function in children with cerebral palsy. Acta. Pediatr., v. 84, n. 6, p. 689-692, jun. 1995.

LEVY, D. S.; RAINHO, L. Abordagem em disfagia infantil proposta foaudiológica e fisioterápica. In: JACOBI, J. S.; LEVY, D. S.; SILVA, L. M. C. Disfagia: avaliação e tratamento. Rio de Janeiro: Revinter., 2003. cap. 4, p. 37-65. LIMONGI, S. C. O. Avaliação e terapia fonoaudiológica do paralítico cerebral. In: TABITH, A. Foniatria. São Paulo: Cortz, 1981. cap. 10, p. 77-117.

LIMONGI, S. C. O. Processo terapêutico fonoaudiológico na paralisia cerebral. In: LIMONGI, S. C. O. Fonoaudiologia - informação para a formação: procedimentos terapêuticos em linguagem. São Paulo: Guanabara, 2003. cap. 5, p. 67-90. LIMONGI, S. C. O.; CARVALLO, R. M. M.; SOUZA, E. R. Auditory processing and language in Down syndrome. $J$. Med. Speech-Lang. Pathology, v. 8, n. 1, p. 27-34, 2000.
MOTION, S.; NORTHST ONE, K.; EMOND, A.; STUCKE, S.; GOLDING J. Early feeding problems in children with cerebral palsy: weight and neurodevelopmental outcomes. Developmental Medicine \& Child Neurology, v. 44, n. 1, p. 40-43, jan. 2002.

NEWMAN, L. A. Optimal care patterns in pediatric patients with dysphagia. Semin. Speech. Lang., v. 21, n. 4, p. 281-291, 2000.

PINNINGTON, L.; HEGARTY, J. Effects of consistent food presentation on oral motor skill acquisition in children with severe neurological impairment. Dysphagia, v. 15, n. 4 , p. 213-223, sept. 2000 .

REDSTONE, F.; WEST, J. F. The importance of postural control for feeding. Pediatric Nursing Journal, v. 30, n. 2, p. 97-100, mar.-apr. 2004.

REILLY, S.; SKUSE, D. Characteristics and management of feeding problems of young children with cerebral palsy. Developmental Medicine \& Child Neurology, v. 34, n. 5, p. 379-388, may. 1992.

SCHWARTZMAN, M. L. C. Aspectos da alimentação na criança com paralisia cerebral. In: LIMONGI, S. C. O. Paralisia cerebral: processo terapêutico em linguagem e cognição (Pontos de Vista e Abrangência). Barueri: PróFono, 2000. cap. 3, p. 35-73.

SEACERO, L. F. Paralisia cerebral: características motoras orais e a relação entre o histórico alimentar e as funções neurovegetativas. 1999. 120 f. Dissertação (Mestrado em Reabilitação) - Universidade Federal de São Paulo, São Paulo.

SILVA, K. C. L.; Limongi, S. C. O.; Flabiano, F. C.; Val, D. C. Relação entre a postura corporal e a respiração em crianças com alterações sensório-motoras. Revista da Sociedade Brasileira de Fonoaudiologia, v. 9, n. 1, p 25-31, jan.-mar. 2004.

SLEIGH, G.; SULLIVAN, P.; THOMAS, A. Gastrostomy feeding versus oral feeding alone for children with cerebral palsy. Cochrabe Database System Review, 2004. 2 CD 003943.

SULLIVAN, P. B.; LAMBERT, B.; ROSE, M.; FORDADAMS, M.; JOHNSON, A.; GRIFFITHS, P. Prevalence and severity of feeding and nutricional problems in children with neurological impairment. Oxford Feeding Study. Developmental Medicine \& Child Neurology, v. 42, n. 10, p. 674-680, oct. 2000.

TROUGHTON, K. E.; HILL, A. E. Relation between objectively measured feeding competence and nutrition in children with cerebral palsy. Developmental Medicine \& Child Neurology, v. 43, n. 3, p. 187-190, mar. 2001.

VERZONI, L. D. N.; LIMONGI, S. C. O. A inter-relação entre os desenvolvimentos neuropsicomotor, cognitivo, de linguagem e do sistema miofuncional oral no período sensório-motor, por meio da análise de dois casos de crianças portadoras de paralisia cerebral. In: LIMONGI, S. C. O. Fonoaudiologia \& pesquisa. São Paulo: Lovise, 1998. cap. 3, p. 63-109. (Série Atualidades em Fonoaudiologia).

WEST, J. F.; REDSTONE, F. Alignment during feeding and swallowing does it matter? A Review. Perceptual and Motor Skills, v. 98, n. 1, p. 349-358, feb. 2004.

WOLF, L. S.; GLASS, R. P. Feeding and swallowing disorders in infancy: assessment and management. Texas: Therapy Skill Builders, 1992. 


\section{Apêndice}

Avaliação do sistema estomatognático e postura - Laboratório de Investigação Fonológica em Síndromes e Alterações Sensório-Motoras (LIF-SASM).

Nome: Data de Nascimento: Idade:

Data do Exame:

\section{1) Lábios:}

Postura no repouso:

( ) Ocluídos ( ) Ocluídos com contração do m. mentalis

( ) Entreaberto ( ) Abertos

Tônus Muscular:

( / ) Adequado ( / ) Aumentado ( / ) Diminuído

Mobilidade:

( ) Protrusão

( ) Retração Lateral E

( ) Retração Lateral D

( ) Estalo

( ) Retração Lateral Simétrica （ ) Contração

( ) Vibração

2) Língua:

Postura no repouso:

( ) Papila ( ) Interdentalizada ( ) Assoalho Bucal

( ) Apoiada nos Incisivos ( ) Marca de Dentes

Tônus:

( ) Adequado ( ) Aumentado ( ) Diminuído

Mobilidade:

( ) Lateralização Interna ( ) Lateralização Externa

( ) Protrusão ( ) Estalo ( ) Elevação em Ponta

( ) Abaixamento ( ) Vibração ( ) Retração

3) Bochechas:

Tônus:

$\begin{array}{ll}\text { ( ) Adequado } & \text { ( ) Aumentado ( ) Diminuído } \\ \text { ( ) Simetria } & \text { ( ) Assimetria }\end{array}$

Mobilidade:

( ) Infla ( ) Suga

( ) Simetria ( ) Assimetria

Sensibilidade:

( ) Adequada ( ) Reduzida ( ) Aumentada

( ) Simetria ( ) Assimetria

4) Palato Mole e Úvula:

Aspecto:

( ) Adequado ( ) Alterado

Úvula:

( ) Normal ( ) Desviada à ( ) Bífida

Palato Mole:

( ) boa mobilidade ( ) mobilidade reduzida

5) Palato Duro:

( ) Adequado ( ) Estreito ou Ogival ( ) Alto

( ) Presença de fístula
6) Amígdalas:

( ) Ausentes ( ) Normais ( ) Hipertróficas

7) Freios:

Freio Labial Superior:

Freio Labial Inferior:

Freio Lingual:

8) Dentes:

Higiene e conservação dos dentes:

Presença de cáries:

( ) Sim ( ) Não

Dentição:

( ) decídua ( ) mista ( ) permanente

Ausência de dentes:

( ) Sim ( ) Não Quais?

Oclusão:

( ) Adequada ( ) Aberta____ ( ) Cruzada

( ) Overjet ( ) Sobremordida ( ) Prognatismo ( ) $\overline{\text { Em topo }}$

9) Hábitos Orais:

10) Preferências Alimentares:

11) Sucção:

Vedamento Labial:

Preensão do bico e/ou canudo:

Eficiência e Força:

( ) forma bico ( ) contrai bucinadores

( ) movimentação póstero-anterior de língua

( ) movimentação póstero-anterior de mandíbula

( ) movimentação vertical de mandíbula

Coordenação com respiração e deglutição:

Utensílios Utilizados:

Tempo de Alimentação:

Observação:

Copo (preensão, retirada do líquido):

12) Mastigação:

Alimento utilizado:

Preensão do alimento: 
Tamanho do pedaço introduzido na boca:
( ) lábios ocluídos
( ) lábios abertos

Movimentação de língua:

Contração de Masséteres:

( ) forte ( ) fraca ( ) simétrica ( ) assimétrica

Contração de Temporais: ( ) forte ( ) fraca ( ) simétrica ( ) assimétrica

Movimentação de Mandíbula:

Uso Preferencial:

( ) lado direito ( ) lado esquerdo ( ) não há Ritmo:

( ) adequado ( ) lento ( ) acelerado

Tempo de Alimentação:

Eficiência:

Colher (tamanho, forma, material, preensão, retirada do alimento):

Observação:

13) Deglutição (líquidos / pastosos / sólidos):

Líquido:

Pastoso:

Sólido:

Coordenação com a respiração:

Observação
14) Presença de Reflexos Patológicos Orais:

15) Atenção da Criança Durante a Alimentação:

16) Relação Mãe e Criança Durante a Alimentação:

17) Respiração:

( ) Nasal ( ) Oral ( ) Mista

18) Postura:

Postura da criança durante a alimentação:

Postura do cuidador durante a alimentação da criança:

Como a mãe manipula a criança?

Como o alimento é oferecido à criança?

Estratégias utilizadas pelo cuidador para um posicionamento mais funcional:

Presença de Reflexos Patológicos Posturais:

( ) RTL ( ) RTCA ( ) RTCS

Observação:

Endereço para correspondência:

Daniela Cristina do Val

R. Arthur Soter Lopes da Silva, 456 - São Paulo - SP - CEP: 05367-140. 